\title{
MINERAL CONTENT OF THREE SEVERAL MUSCLES FROM SIX CATTLE GENOTYPES
}

\author{
T. Somogyi ${ }^{\mathrm{a}}$, I. Hollóa , J. Csapóa , I. Anton ${ }^{\mathrm{b}}$ and G. Hollóa* \\ ${ }^{a}$ Faculty of Agricultural and Enviromental Sciences, Kaposvár University, \\ H-7400 Kaposvár, Guba Sándor u. 40. Hungary \\ ${ }^{\mathrm{b}}$ Research Institute for Animal Breeding and Nutrition, H-2053 Herceghalom, Gesztenyés út 1. Hungary
}

(Received: 3 January 2012; accepted: 24 April 2014)

\begin{abstract}
The aim of this study was to determine the effect of genotype and type of muscle on the mineral content of beef. Altogether 62 young bulls from Angus, Charolais, Holstein, Hungarian Simmental, Hungarian Grey, and Charolais $\times$ Hungarian Grey were used. The calcium content varied between $26-46 \mathrm{mg} \mathrm{kg}^{-1}$, in longissimus muscle of Hungarian Simmental it was significantly higher than for other genotypes except for Angus. Psoas major of Holstein had the highest phosphorus content, it significantly differed from the longissimus of Angus. Longissimus muscle of Angus was the poorest for magnesium, and the richest was the psoas major of Holstein and Hungarian Grey. Charolais had higher level of potassium in psoas major than Angus and Charolais $\times$ Hungarian Grey. Sodium content of semitendinosus in Charolais $\times$ Hungarian Grey was lower than in Holstein. Present data showed that richest source of iron was the beef from Hungarian Grey, especially psoas major muscle. The highest manganese and copper levels were detected in the longissimus of Angus and semitendinosus of Holstein. Concerning zinc, a higher level was found in longissimus, especially for Holstein. The results confirmed that beef mineral content depends on genotype, and is related to muscle type, too.
\end{abstract}

Keywords: cattle, beef quality, minerals, muscle type

Beef is an essential source of high biological value proteins and vitamins, in addition beef is rich in several important mineral elements (BIESALSKI, 2005), particularly Fe (SAUCIER, 1999). To ensure the mineral element needs of the human body, the consumption of red meats is recommended (NoHR \& BIESALSKI, 2007), because red meats contain essential minerals (Fe, $\mathrm{Zn}, \mathrm{Se})$ and the biological availability is better than in plants. According to the results of human nutrition surveys in the USA (KENNEDY \& GoldBerg, 1995) and UK (GREGORY et al., 1995), the intake of $\mathrm{Ca}, \mathrm{Zn}$, and Fe is often low, while the intake of Na and Mg exceeds the recommended daily needs. Only a few articles deal with the mineral element content of beef. GERBER and co-workers (2009) emphasize that the exact mineral content of meat is important to know, the evaluation of the nutritive value without this is unpredictable, so the calculated human nutrition recommendations may not be accurate. According to the literature, the concentration of mineral elements of beef is affected by animal age (SCHÖNFELDT \& GIBSON, 2008), breed (CABRERA et al., 2010), gender (López-Alonso et al., 2000), muscle type (Purchas \& Bushboom, 2005; Cabrera et al., 2010), feeding system (Holló et al., 2007), and cooking and processing methods (LomBARDI-Boccia et al., 2005). According to the studies, the concentrations of minerals differ in the different muscles. The $\mathrm{K}$ content is higher in semitendinosus muscles, as in the longissimus and supraspinatus muscles, while the Na level is the highest in the supraspinatus, regarding the three muscles (BARGE et al., 2005). It seems

\footnotetext{
* To whom correspondence should be adressed. Phone:+36-82-502-049; e-mail: hollo.gabriella@sic.ke.hu
} 
that Zn content (Kotula \& LusBy, 1982; Barge et al., 2005) is in a higher proportion in the less valuable meat cuts ( $m$. supraspinatus, $m$. transversus abdominis) than in the first class meat cuts. Similar to the Zn content, the Fe content alters in the individual muscles, too, the Fe content of oxidative red muscles is higher (HoLló et al., 2008). CABRERA and Co-workers (2010) compared the Se, $\mathrm{Cu}, \mathrm{Zn}, \mathrm{Fe}$, and Mn contents in seven different meat cuts of Hereford and Bradford steers, and found that the effect of meat type is much more pronounced than the effect of breed, and the former is significant for all elements.

Consequently, the aim of this study was to compare the mineral content of three different indicator meat cuts from six cattle genotypes - bulls kept and fed under same conditions -, and to evaluate the nutritional value of beef.

\section{Materials and methods}

\subsection{Animals, fattening conditions}

Sixty-two Angus (A), Charolais (CH), Holstein (H), Hungarian Simmental (HS), Hungarian Grey purebred $(\mathrm{HG})$, and Charolais $\times$ Hungarian Grey crossbred $(\mathrm{CH} \times \mathrm{HG})$ young bulls were included in the experiment. The animals were kept in small breed groups in a loose housing system, and were fattened under semi-intensive conditions, ad libitum maize silage, grass hay, and moderate concentrate supplementation (in the finishing period of fattening the concentrate contained $25 \%$ linseed). The average final weight and age of bulls were $621.61 \pm 25.09 \mathrm{~kg}$ and $656.52 \pm 87.28$ day, respectively.

\subsection{Slaughtering, sampling}

The animals were slaughtered at similar live weight at the commercial abattoir according to Hungarian Standard (1977). Meat samples were taken from three high commercial value meat cuts (loin, tenderloin, eye of round) from three indicator muscles ( $M$. longissimus dorsi (LD), M. psoas major (PM), M. semitendinosus (ST)) to determine the mineral content of beef. The samples have been taken after 24 hours chilling from the right half carcass.

\subsection{Chemical analysis, determination of mineral elements}

The chemical examinations were carried out in the Analytical Laboratory of Kaposvár University, Faculty of Animal Science. The dry matter and the ash content of the meat samples were determined according to the relevant standards (Hungarian STANDARD, 1980; Hungarian Standard, 2000). The $\mathrm{Ca}, \mathrm{Cu}, \mathrm{Fe}, \mathrm{Mg}$, Na, K, and Zn contents were determined with atomic absorption spectrometer (SOLAAR M6) in accordance with the EU standards (EN ISO, 2000), while the P content was determined with spectrometric method according to the international standard (ISO, 1998).

\subsection{Statistical analysis}

For the statistical evaluation the SPSS 20.0 software (2011) was used. In addition to basic statistical results (mean, SD), the effect of breed and muscle type was evaluated with multivariate analysis of variance, general linear model (GLM) III. The differences among the groups were evaluated with Tukey's test, the level of significance was set at $\mathrm{P}<0.05$. 


\section{Results and discussion}

This paper is part of a larger study, the slaughter and boning results are presented by HoLLó and co-workers (2012). There were significant differences observed in the chemical composition among the different meat cuts and the genotypes (Table 1). The highest dry matter content was determined in the A bulls. The crude protein content was the highest in the HS bulls compared with the other breeds, except for $\mathrm{CH} \times \mathrm{HG}$ crosses. Significantly less crude fat was measured in $\mathrm{H}$ bulls, against $\mathrm{A}, \mathrm{HG}$, and $\mathrm{CH} \times \mathrm{HG}$ young bulls. The crude ash content differed between $\mathrm{A}$ and $\mathrm{CH}$, as well as between $\mathrm{A}$ and $\mathrm{H}$ animals. Moreover, differences were established between the different muscles, too. The PM and LD muscle contained higher amount of dry matter than the ST muscle. The crude protein and crude fat contents were affected by the muscle type in the case of all three meat cuts, while the crude ash amount differed only between PM and LD muscles.

Table 2 presents the mineral content of muscles. For LD muscle, there were significant differences calculated between the elements, except Na. The meat of HS contained the highest amount of $\mathrm{Ca}$, while the other genotypes contained significantly less, except A bulls.

HoLló and co-workers (2007) compared the calcium content in the LD muscle of HG and $\mathrm{H}$ young bulls, and found a higher amount of $\mathrm{Ca}$ in $\mathrm{H}$ than in $\mathrm{HG}$. Ca is one of the mineral elements that is in relationship with other meat quality attributes. According to JEREZ-TimauRE and co-workers (2006), there is a strong correlation between the Ca content of Zebu meat and tenderness. Higher amount of $\mathrm{P}$ was found for the $\mathrm{H}$ bulls, the other breeds contained significantly less, except the $\mathrm{CH} \times \mathrm{HG}$ crosses. The $\mathrm{P}$ content of beef was affected by feeding regime (HoLló et al. 2007), the extensively fed animals accumulated more $\mathrm{P}$ in the meat than the intensively fed ones. The measured $\mathrm{P}$ concentration was higher than in the literature (Hermida et al., 2006; Schönfeldt \& Gibson, 2008). According to the previous articles, the Mg content of beef was not influenced by feeding and breed (HoLLó et al., 2007) and age (BARGE et al., 2005). In our study, the Mg content was higher in beef from HG animals than in beef from HS and A. The loin from $\mathrm{CH}$ was characterized with the highest amount of $\mathrm{K}$, and differed significantly from the loins of A, purebred HG, and $\mathrm{CH} \times \mathrm{HG}$ crosses. HoLLó and co-workers (2007) indicated that extensively held HG bulls stored lower amount of Na, which is beneficial in human nutrition aspects, because the low Na content was accompanied by higher level of $\mathrm{K}$. The LD muscle of A animals contained the highest amount of Mn, while the $\mathrm{CH}, \mathrm{H}$, and $\mathrm{HG}$ breeds contained the less. The concentrations of $\mathrm{Cu}$ and $\mathrm{Zn}$ were the highest in H's meat, which differed in case of the former element from $\mathrm{CH}$, HG, and HS concentrations, while in the case of the latter element from HS. The $\mathrm{Zn}$ and $\mathrm{Cu}$ concentrations of the loin from HS were similar, as Holló and co-workers (2008) demonstrated. The $\mathrm{Cu}$ content of German Simmental's loin is higher (1.14-1.65 mg kg-1), however the $\mathrm{Zn}$ content was below (29-32 $\mathrm{mg} \mathrm{kg}^{-1}$ ) in the HS (MAнECHA et al., 2009). Among the farm animals, the highest concentration of $\mathrm{Zn}$ is located in beef and veal (LomBARDi-Boccia et al., 2005), the presence of $\mathrm{Zn}$ in human body is essential for the proper function of the immune system. The Fe content of H's loin significantly surpassed the Fe contents of A, $\mathrm{CH}$, and HS breeds. The Fe content in HS was higher, as МАнЕснA and co-workers (2009) indicated in the case of German Simmental bulls slaughtered at similar age (12-14 $\left.\mathrm{mg} \mathrm{kg}^{-1}\right)$. 
Table 1. Chemical composition of the different muscles and genotypes (\%)

\begin{tabular}{|c|c|c|c|c|c|}
\hline Genotypes & Muscle & Dry matter & Crude protein & Crude fat & Crude ash \\
\hline \multirow[t]{4}{*}{ A } & LD & $26.84 \pm 1.3$ & $21.47 \pm 0.8$ & $4.42 \pm 1.9$ & $1.02 \pm 0.07$ \\
\hline & ST & $24.54 \pm 0.7$ & $21.39 \pm 0.6$ & $2.11 \pm 0.87$ & $1.02 \pm 0.2$ \\
\hline & $\mathrm{PM}$ & $26.49 \pm 1.2$ & $20.62 \pm 0.5$ & $4.74 \pm 1.4$ & $1.07 \pm 0.07$ \\
\hline & Mean & $25.96 \pm 1.5^{\mathrm{a}}$ & $21.16 \pm 0.7^{\mathrm{a}}$ & $3.76 \pm 1.8^{\mathrm{a}}$ & $1.04 \pm 0.1^{\mathrm{a}}$ \\
\hline \multirow[t]{4}{*}{$\mathrm{CH}$} & LD & $24.46 \pm 0.8$ & $21.58 \pm 0.4$ & $1.85 \pm 0.7$ & $1.06 \pm 0.05$ \\
\hline & ST & $23.76 \pm 0.9$ & $21.11 \pm 0.5$ & $1.58 \pm 0.5$ & $1.11 \pm 0.04$ \\
\hline & $\mathrm{PM}$ & $25.46 \pm 1.2$ & $20.64 \pm 0.9$ & $3.56 \pm 1.9$ & $1.13 \pm 0.07$ \\
\hline & Mean & $24.56 \pm 1.2^{\mathrm{b}}$ & $21.11 \pm 0.7^{\mathrm{a}}$ & $2.33 \pm 1.5^{b c}$ & $1.10 \pm 0.06^{\mathrm{b}}$ \\
\hline \multirow[t]{4}{*}{$\mathrm{H}$} & LD & $25.02 \pm 1.2$ & $21.51 \pm 0.6$ & $2.27 \pm 1.2$ & $1.11 \pm 0.05$ \\
\hline & ST & $23.76 \pm 0.8$ & $21.45 \pm 0.5$ & $1.15 \pm 0.4$ & $1.12 \pm 0.04$ \\
\hline & $\mathrm{PM}$ & $24.75 \pm 0.9$ & $20.61 \pm 0.7$ & $2.91 \pm 0.8$ & $1.12 \pm 0.09$ \\
\hline & Mean & $24.51 \pm 1.09^{b}$ & $21.19 \pm 0.7^{\mathrm{a}}$ & $2.11 \pm 1.1^{\mathrm{c}}$ & $1.12 \pm 0.06^{\mathrm{b}}$ \\
\hline \multirow[t]{4}{*}{$\mathrm{HG}$} & LD & $25.94 \pm 1.7$ & $21.54 \pm 0.4$ & $3.45 \pm 1.7$ & $1.05 \pm 0.05$ \\
\hline & ST & $24.40 \pm 1.01$ & $21.33 \pm 0.5$ & $2.15 \pm 0.8$ & $1.06 \pm 0.05$ \\
\hline & $\mathrm{PM}$ & $26.15 \pm 1.2$ & $20.29 \pm 0.4$ & $4.60 \pm 1.7$ & $1.11 \pm 0.03$ \\
\hline & Mean & $25.50 \pm 1.5^{\mathrm{ac}}$ & $21.05 \pm 0.7^{\mathrm{a}}$ & $3.40 \pm 1.7^{\mathrm{a}}$ & $1.07 \pm 0.05^{\mathrm{ab}}$ \\
\hline \multirow[t]{4}{*}{ HS } & LD & $25.51 \pm 1.5$ & $22.07 \pm 0.5$ & $2.41 \pm 1.6$ & $1.06 \pm 0.05$ \\
\hline & ST & $24.39 \pm 0.8$ & $21.59 \pm 0.5$ & $1.62 \pm 0.8$ & $1.10 \pm 0.07$ \\
\hline & $\mathrm{PM}$ & $24.95 \pm 1.07$ & $21.17 \pm 0.6$ & $2.61 \pm 1.3$ & $1.09 \pm 0.1$ \\
\hline & Mean & $24.95 \pm 1.2^{\mathrm{bc}}$ & $21.61 \pm 0.6^{\mathrm{b}}$ & $2.21 \pm 1.3^{\mathrm{bc}}$ & $1.08 \pm 0.07^{\mathrm{ab}}$ \\
\hline \multirow[t]{4}{*}{$\mathrm{CH} \times \mathrm{HG}$} & LD & $25.98 \pm 0.8$ & $21.89 \pm 0.5$ & $3.08 \pm 0.9$ & $1.03 \pm 0.05$ \\
\hline & $\mathrm{ST}$ & $24.92 \pm 0.7$ & $21.63 \pm 0.4$ & $2.17 \pm 0.5$ & $1.11 \pm 0.06$ \\
\hline & $\mathrm{PM}$ & $25.78 \pm 0.9$ & $20.59 \pm 0.4$ & $3.91 \pm 1.04$ & $1.1 \pm 0.0$ \\
\hline & Mean & $25.56 \pm 0.9^{\mathrm{ac}}$ & $21.37 \pm 0.7^{\mathrm{ab}}$ & $3.05 \pm 1.08^{\mathrm{ab}}$ & $1.08 \pm 0.06^{\mathrm{ab}}$ \\
\hline \multirow{3}{*}{$\begin{array}{l}\text { Overall } \\
\text { mean }\end{array}$} & $L D$ & $25.62 \pm 1.4^{\mathrm{B}}$ & $21.71 \pm 0.6^{\mathrm{C}}$ & $2.87 \pm 1.6^{\mathrm{C}}$ & $1.06 \pm 0.06^{\mathrm{B}}$ \\
\hline & $S T$ & $24.30 \pm 0.9^{\mathrm{A}}$ & $21.44 \pm 0.5^{\mathrm{A}}$ & $1.77 \pm 0.7^{\mathrm{A}}$ & $1.09 \pm 0.09^{\mathrm{AB}}$ \\
\hline & $P M$ & $25.52 \pm 1.2^{\mathrm{B}}$ & $20.7 \pm 0.62^{\mathrm{B}}$ & $3.60 \pm 1.5^{\mathrm{B}}$ & $1.10 \pm 0.07^{\mathrm{A}}$ \\
\hline
\end{tabular}

a,b,c different superscripts in the same row indicate statistically significant differences among genotypes $(\mathrm{P}<0.05)$ $\mathrm{A}, \mathrm{B}, \mathrm{C}$ different superscripts in the same row indicate statistically significant differences among muscles $(\mathrm{P}<0.05)$ 


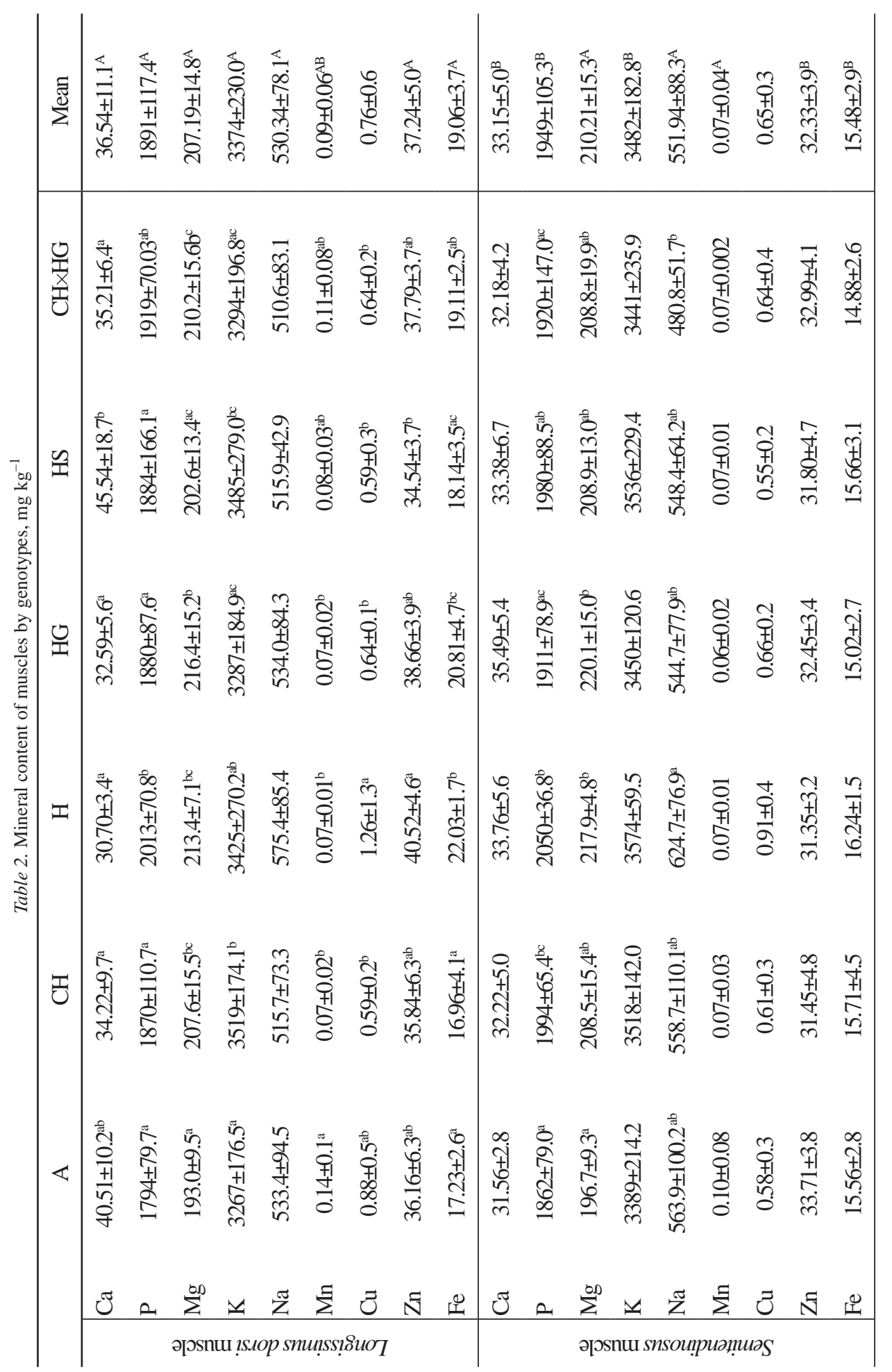


The mineral content of semitendinosus muscle shows that significant differences were calculated in the case of $\mathrm{P}, \mathrm{Mg}$, and $\mathrm{Na}$. A similar trend was observed for these three elements as for longissimus muscle. The highest $\mathrm{P}$ and $\mathrm{Na}$ concentrations were experienced in $\mathrm{H}$, while the highest Mg content was measured in HG animals. The P content in ST muscle of H was higher than in A, while the Na content surpassed the HG animals. Similar to the LD muscle, higher Mn concentration was observed in $\mathrm{A}$, and higher $\mathrm{Cu}$ and Fe contents were observed in $\mathrm{H}$ bulls. The ST muscles of HG and A animals were characterized with the highest $\mathrm{Ca}$ and $\mathrm{Zn}$ contents, respectively, unlike LD muscle. The differences are not significant in the case of $\mathrm{Mn}, \mathrm{Cu}, \mathrm{Fe}, \mathrm{Ca}$, and Zn elements.

The mineral content of the psoas major muscle differed significantly in the case of $\mathrm{P}$, $\mathrm{Mg}, \mathrm{K}$, and Fe among the genotypes. The $\mathrm{P}$ and $\mathrm{Mg}$ contents of Holstein's muscle were higher than those of $\mathrm{A}$. The meat of $\mathrm{A}$ and $\mathrm{CH} \times \mathrm{HG}$ contained less $\mathrm{K}$ than that of $\mathrm{CH}$. The eye of round of HG animals was the richest in Fe, the other genotypes accumulate much less Fe, except crossbred animals. The highest calcium concentration was measured in the case of HG animals, in tenderloin, while $\mathrm{H}$ was richest in $\mathrm{Na}$ in loin and tenderloin. The $\mathrm{Cu}, \mathrm{Zn}, \mathrm{Fe}$, and Mn concentrations were different among the other muscles. The meat of HG was the richest in $\mathrm{Cu}, \mathrm{Zn}$, and $\mathrm{Fe}$, while the meat of $\mathrm{CH}$ in $\mathrm{Mn}$.

The muscle type had significant effect on the element contents, except for $\mathrm{Cu}$. According to the literature, the Cu content of the meat is affected by muscle type (HoLLó et al., 2008; CABRERA et al., 2010), furthermore, differences were reported between variant muscles in Fe (Purchas \& Bushboom, 2005; Holló et al., 2008; Cabrera et al., 2010), Zn (Barge et al., 2005; Holló et al., 2008; Cabrera et al., 2010), Mn (CABrera et al., 2010), K, and Na (Gillet et al., 1967; BARge et al., 2005) concentrations. The loin was the richest in $\mathrm{Ca}, \mathrm{Cu}$, and $\mathrm{Zn}$, while the eye of round in $\mathrm{K}$ and $\mathrm{Na}$, and the tenderloin in $\mathrm{P}, \mathrm{Mg}, \mathrm{Mn}$, and Fe. The $\mathrm{Zn}$ content in the tested muscles varied between 27 and $37 \mathrm{mg} \mathrm{kg}^{-1}$. WiLLIAMson and co-workers (2005) reported higher values in samples from four countries (Denmark, UK, Australia, USA). CABRERA and co-workers (2010) found similar results to our study, in the case of Uruguay Hereford and Bradford steers. This is probably due to the low Zn concentration in soil and plants in Uruguay (Morón \& Baethgen, 1998) like in Hungary, where the soil is poor in $\mathrm{Zn}$, too. The $\mathrm{Zn}$ concentration of beef (18-42 $\mathrm{mg} \mathrm{kg}^{-1}$ ) in Uruguay is higher than reported by LomBARDi-Boccia and co-workers (2005), WiLLIAMSON and co-workers (2005), GERBER and co-workers (2009), and then our results (18.8 $\mathrm{mg} \mathrm{kg}^{-1}$ ), too. With respect to $\mathrm{Mn}$, our results were similar to the US and higher than the Swiss results (GERBER et al., 2009). The Ca content was considerably lower than in the studies by LEHESKA and co-workers (2008) and SCHÖNFELDT and GiBson (2008), but similar to the results reported by GiUfFridA-MENDOZA and co-workers (2007) and Holló and co-workers (2007). According to the previous articles (Barge et al., 2005; Giuffrida-Mendoza et al., 2007; Schönfeldt \& Gibson, 2008), the bovine muscles are rich in $\mathrm{K}$ and $\mathrm{P}$. In our examination the effect of muscle was significant, the amounts of $\mathrm{P}$ and $\mathrm{K}$ were less in LD muscle. The Mg content was higher in the LD muscle and in the average of the three muscles too, than in our previous study (197 $\mathrm{mg} \mathrm{kg}^{-1}$ ). In the PM muscle more Mg was found, compared to the other muscles. The Na content was much favourable in PM muscle, too, because it contains less Na. However, the average Na concentration is much less - more favourable from the human nutritional point of view - in the beef measured from south America (Giuffrida-Mendoza et al., 2007), South Africa (Schönfeldt \& GiBson, 2008), and North America (LehESKa et al., 2008). The lower Na content is more favourable, because adults consume three times more $\mathrm{Na}$ than the recommended level (DESMOND, 2006). 
In the case of the investigated genotypes, there were significant differences observed in the average concentration of four elements: P, Mg, K, and Na. The H breed was characterized by the highest $\mathrm{P}, \mathrm{Na}$, and $\mathrm{Cu}$ contents, furthermore, the $\mathrm{Mn}$, Zn, and Fe contents of the HG are outstanding. The highest $\mathrm{Ca}, \mathrm{Mn}$, and $\mathrm{K}$ contents were calculated similarly in the order $\mathrm{HS}, \mathrm{A}$, and $\mathrm{CH}$ animals. The A bulls accumulated less $\mathrm{P}, \mathrm{Mg}$, and $\mathrm{K}$. The beef of $\mathrm{CH}$ was poor in $\mathrm{Cu}, \mathrm{Zn}$, and $\mathrm{Fe}$, the beef of $\mathrm{CH} \times \mathrm{HG}$ in $\mathrm{Na}$, while the beef of $\mathrm{H}$ in $\mathrm{Ca}$.

For adults, recommended daily intake of $\mathrm{Zn}$ is $10 \mathrm{mg}$ (EEC, 2008). Experimental results show that beef is an excellent source of $\mathrm{Zn}$, because the consumption of $100 \mathrm{~g}$ beef from the investigated genotypes can ensure a greater proportion of the certified daily needs (31-33\%). Consuming the same amount of beef can provide $26-29.28 \%$ of the daily P needs (700 mg), $16.6-17.85 \%$ of the daily K needs (2000 mg), and $13-15.7 \%$ of the daily Fe needs (14 mg).

\section{Conclusions}

Beef is an excellent source of important elements, contains $\mathrm{K}, \mathrm{P}, \mathrm{Na}$, and $\mathrm{Mg}$ in higher amounts, as well as a significant source of $\mathrm{Zn}$ and Fe. Among the three investigated muscle types, the most significant difference in the mineral elements contents was in the LD muscle. In the case of $\mathrm{P}$ and $\mathrm{Mg}$, the effect of genotype was great in all three muscle types. The mineral concentration was affected by muscle type for all elements, except $\mathrm{Cu}$. The loin was the richest in $\mathrm{Ca}$ and $\mathrm{Zn}$, the eye of round in $\mathrm{K}$ and $\mathrm{Na}$, and the tenderloin in $\mathrm{P}, \mathrm{Mg}, \mathrm{Mn}$, and $\mathrm{Fe}$. The average $\mathrm{P}$ and $\mathrm{Na}$ contents of the meat of $\mathrm{H}$ were the highest among genotypes, while the $\mathrm{P}, \mathrm{Mg}$, and $\mathrm{K}$ contents of A were the lowest. The meat of HG was characterised with the largest amount of $\mathrm{Mg}$, and the meat of $\mathrm{CH}$ with potassium. From the human nutritional point of view, favourable low Na level was found in the meat of $\mathrm{HG}$ and $\mathrm{CH} \times \mathrm{HG}$ animals. By the consumption of hundred g beef, 31-33\% of the recommended daily Zn needs can be ensured, which amount varied within 26-29\%, 16.6-17.9\%, and 13-15.7\% in the P, K, and Fe needs, respectively.

The authors are grateful to OTKA CK 78289, "Molecular genetic and cross-sectional imaging methods to improve bovine meat quality and nutritive value of milk” project for financial support.

\section{References}

Barge, M.T., Piccone, G., Barge, P. \& Cignetti, A. (2005): Preliminary results on mineral content of some beef muscles. Ital. J. Anim. Sci., 4 (Suppl. 2), 272-274.

BiesAlski, H.K. (2005): Meat as a component of a healthy diet - are there any risks of benefits if meal is avoided in the diet? Meat Sci., 70, 509-524.

Cabrera, M.C., Ramos, A., SaAdoun, A. \& Brito, G. (2010): Selenium, copper, zinc, iron and manganese content of seven meat cuts from Hereford and Bradford steers fed pasture in Uruguay. Meat Sci., 84, 518-528.

Desmond, E. (2006): Reducing salt: A challenge for meat industry. Meat Sci., 74, 188-196.

EEC (2008): Commission directive 2008/100/EC of 28 October 2008 amending council directive 90/496/EEC on nutrition labelling for foodstuffs as regards recommended daily allowances, energy conversion factors and definitions. OJ., 285, 9-12.

EN ISO (2000): Animal feeding stuffs - Determination of the contents of calcium, copper, iron, manganese, potassium, sodium and zinc - method using atomic absorption spectrometry. EN ISO 6869:2000.

Gerber, N. Brogioli, R., Hattendorf, B., Scheeder, M.R.L., Wenk, C. \& Günther, D. (2009): Variability of selected trace elements of different meat cuts determined by ICP-MS and DRC-ICMS. Animal, 3, 166-172. 
Gillet, T.A., Pearson, A.M., Allen, D.M. \& Merkel, R.A. (1967): Variation in potassium and sodium content of bovine muscles. J. Anim. Sci., 24, 46-49.

Giuffrida-Mendoza, M., Arenas de Moreno, L., Uzcátegui-Bracho, S., Rincón-Villalobos, G. \& HuertaLEIDENZ N. (2007): Mineral content of longissimus dorsi thoracis from water buffalo and Zebu-influenced cattle at four comparative ages. Meat Sci., 75, 487-493.

Gregory, J.R., Collins, D.L., Davies, P.S., Hughes, J.M. \& Clarke, P.C. (1995): National diet and nutrition survey: children aged 1.5 to 4.5 years. Vol. 1: Report of the diet and nutrition survey. London, HMSO

Hermida, M., Gonzalez, M., Miranda, M. \& Rodrígez-Otero, J.L. (2006): Mineral analysis in rabbit meat from Galicia (NW Spain). Meat Sci., 73, 635-639.

Holló, G., Nuernberg, K., Ender, K., Lóki, K., Seregi, J. \& Holló, I. (2008): Carcass characteristics and meat quality of Hungarian Simmental young bulls fed different forage to concentrate ratio with or without linseed supplementation. Arch. Tierzucht, 51, 517-530.

Holló, G., Nuernberg, K., Holló, I., Csapó, J., Seregi, J., Repa, I. \& Ender, K. (2007): Effect of feeding on the composition of longissimus muscle of Hungarian Grey and Holstein Friesian bulls III. Amino acid composition and mineral content. Arch. Tierzucht, 50, 575-586.

Holló, G., Nuernberg, K., Somogyi, T., Anton, I. \& Holló, I. (2012): Comparison of fattening performance and slaughter value of local Hungarian cattle breeds to international breeds. Arch. Tierzucht, 55, 1-12.

ISO (1998): Animal feeding stuffs - Determination of phosphorus content - Spectrometric method. ISO 6491

Jerez-Timaure, N., Arenas De Moreno, L., Colmenares, C. \& Navas-Sánchez, Y. (2006): Canonical correlation between mineral content and meat quality traits of buffalo and zebu-type cattle. Proceeding of $52^{\text {nd }}$ International Congress of Meat Science and Technology, 725-726.

Hungarian Standard (1977): Szarvasmarha húsának hússzéki darabolása (Retail cutting of beef). MSZ 6935-77, 6 pages.

Hungarian Standard (1980): Húskészítmények vizsgálati módszerei. Szárazanyag- és víztartalom meghatározása (Test methods for meat products: Determination of dry matter and water content). MSZ 5874-4:1980, 5 pages.

Hungarian Standard (2000): Hús és húskészítmények. Hamutartalom meghatározása (Meat and meat products. Determination of total ash). MSZ ISO 936:2000, 7 pages.

Kennedy, E. \& GoldBerg, J. (1995): What are American children eating? Implications for public policy. Nutr. Rev., 53(5), 111-126.

Kotula, A.W. \& Lusby, W.R. (1982): Mineral composition of muscles of 1- to 6-year-old steers. J. Anim. Sci., 54, 544-548.

Leheska, J.M., Thompson, L.D., Howe, J.C., Hentges, E., Boyce, J., Brooks, J.C., Shriver, B., Hoover, L. \& Miller, M.F. (2008): Effects of conventional and grass-feeding systems on the nutrient composition of beef. J. Anim. Sci., 86, 3575-3585.

Lombardi-Boccia, G., Lanzi, S. \& Aguzzi, A. (2005): Aspects of meat quality: trace elements and B vitamins in raw and cooked meats. J. Food Compos. Anal., 18, 39-46.

López Alonso, M., Benedito, J.L., Miranda, M., Castillo, C., Hernández, J. \& Shore, R.F. (2000): Arsenic, cadmium, lead, copper and zinc in cattle from Galicia, NW Spain. Sci. Total Environ., 246, 237-248.

Mahecha, L., Nuernberg, K., Nuernberg, G., Ender, K., Hagemann, E. \& Dannenberger, D. (2009): Effects of diet and storage on fatty acid profile, micronutrients and quality of muscle from German Simmental bulls. Meat Sci., 82, 365-371.

Morón, A. \& Baethgen, W. E. (1998): Micronutrient status in dairy farms of Uruguay. Proceeding of the 16th World Congress of the Science of the Ground, International Soil Science Society, ISSS/AFES, Symposium, August 20-26, Montpellier, France, http://natres.psu.ac.th/Link/SoilCongress/bdd/symp14/2162-t.pdf (last accessed: 24. April 2014).

Nohr, D. \& BiESALSKI, H.K. (2007): "Mealthy food”: meat as a healthy and valuable source of micronutrients. Animal, 1, 309-316.

Purchas, R.W. \& Busboom, J.R. (2005): The effect of production system and age on levels iron, taurine, carnosine, coenzyme $\mathrm{Q}_{10}$, and creatine in beef muscles and liver. Meat Sci., 70, 589-596.

SAUCIER, L. (1999): Meat safety: Challenges for the future. Nutr. Abs. Rev., Ser. A., 69, 705-708, http://cmsa-ascv.ca/ documents/1999July-99Saucierpgs3-11.pdf (last accessed: 25 September 2014).

SchöNFELDT, H.C. \& GiBSON, N. (2008): Changes in the nutrient quality of meat in an obesity context. Meat Sci., 80, $20-27$.

Williamson, C.S., Foster, R.K., Stanner, S.A. \& Buttris, J.L. (2005): Red meat in the diet. British Nutrition Foundation, Nutrition Bulletin, 30, 323-335. 